\title{
Molecular identification of blast resistance genes in rice genotypes using gene-specific markers
}

\author{
Mohammed I. Al-DaEJ ${ }^{1}$, Mohamed Ismail ${ }^{2 *}$, Adel A. ReZK ${ }^{1,3}$, MohaMed M. El-MaLKY ${ }^{4}$ \\ ${ }^{1}$ Department of Biotechnology, College of Agriculture and Food Sciences, King Faisal University, Saudi Arabia \\ ${ }^{2}$ Genetics Department, Faculty of Agriculture, Menoufia University, Shibin El-Kom, Egypt \\ ${ }^{3}$ Department of Virus and Phytoplasma Research, Plant Pathology Research Institute, Agricultural Research Center, Egypt \\ ${ }^{4}$ Rice Research and Training Center, Field Crops Research Institute, Agricultural Research Center, Egypt
}

\begin{abstract}
Molecular identification of major blast resistance $(R)$ genes in rice was performed in a group of 10 rice (Oryza sativa) genotypes from Egypt and Saudi Arabia using six DNA markers (T8042, NSB, YL153/YL154, RM3843, RM3330, and z4794) belonging to three classes: single-nucleotide polymorphisms (SNPs), simple sequence repeats (SSRs), and insertion-deletions (InDels). The markers were chosen based on their linkage to six major Rgenes (Pit, Pib, Pi39(t), Pi40(t), Piz/Piz-t, and Pita/Pita2). The studied markers showed low allelic diversity, with the number of alleles identified in a single genotype ranging between two and nine alleles. The Egyptian genotype Eg-N-7 had two alleles of the Pi4O(t) gene, while the Saudi Arabian genotype Al-Ahsa1 had nine alleles that belonged to the seven $R$ genes. The studied genotypes were also assessed for 19 agro-morphological traits. Analysis of variance of the studied traits showed significant differences among the genotypes. The putative associations between molecular markers and the agro-morphological traits were examined using associationmapping approach by employing the unified mixed model. Eight significant marker-trait associations were detected for eight agro-morphological traits (plant height, panicle length, sterility percentage, grain width, grain shape, elongation percentage, gelatinization temperature, and days to maturity). The phenotypic variance shown by each marker ranged between $43 \%$ and $65 \%$. The findings of the current study will assist in identifying possible blast resistance genotypes for future rice breeding programs. Additionally, the results highlight the possible dual usage of specific markers in genotypic screening as well as in determining marker-trait associations.
\end{abstract}

Key words: association genetics, molecular markers, Oryza sativa, rice blast resistance

\section{Introduction}

Rice (Oryza sativa L.) is one of the most planted crops in the world, providing staple food for a large human population worldwide (Khush, 2005). Annual rice consumption has been increasing due to a steady growth in human population (Muthayya, 2014). Many factors are known to produce a significant impact on rice production in Asia and Africa (Aksoy and Beghin, 2005). The major factors affecting rice production are the shortage of water, insects, and diseases, in addition to other biotic and abiotic stress factors. One of the most destructive diseases that affects the rice production worldwide is blast disease caused by the fungus Magnaporthe oryzae (Li et al., 2007). The yield loss is estimated to be between 10\% and 30\% (Skamnioti et al., 2009). Many approaches have been developed over a century to combat the disease, which primarily dealt with, but were not limited to, chemical control, water management, time of planting, biological control, and breeding (Srivastava et al., 2017). One of the most effective strategies to fight blast disease is to develop resistant varieties. Plants defend themselves against pathogens at different levels: structure barriers (e.g., cell walls), pathogen pattern recognition, and defense against specific pathogen race

\footnotetext{
* Corresponding author: Genetics Department, Faculty of Agriculture, Menoufia University, Shibin El-Kom, Egypt; e-mail: mohamed.ismail@agr.menofia.edu.eg
} 
(Yang et al., 2013). The latter mechanism is usually adopted by the rice plant to provide protection against $M$. oryzae (Yang et al., 2013). In this process, resistant $(R)$ genes are activated by plant pathogen effectors, thus triggering an antimicrobial response which eventually leads to the genotype being resistant or susceptible to the infection (Liao et al., 2016). $R$ genes in plants are considered to be one of the major resistance components and are always associated with a hypersensitive response according to the gene-for-gene concept $(\mathrm{Fu}-$ kuoka et al., 2009). Resistance genes for rice blast are generally identified in landraces and/or wild rice using physiological races of $M$. oryzae (Tanksley and McCouch, 1997). The use of conventional breeding techniques to transfer $R$ genes allowed for the successful development of many blast resistance genotypes (Miah et al., 2013). On the other hand, molecular breeding techniques, which utilize DNA markers that are tightly linked to the blast $R$ genes, provide a great contribution to the breeding programs. The complete genome sequencing of rice (Matsumoto et al., 2005) and the availability of different DNA markers (Huda et al., 2019) have made possible the identification of major resistance genes that confer resistance in different genotypes (Yildirim et al., 2018). The identification of blast resistance genes is crucial for breeding programs, and approximately 100 genes were identified as major $R$ genes in rice germplasm in addition to 350 quantitative trait loci (QTL) associated with resistance to rice blast (Fukuoka et al., 2014). Pi genes, among many genes, have been identified, mapped, and characterized (Causse et al., 1994; Wang et al., 1994; Wang et al., 2014). Since each $R$ gene contributes to a small portion of blast resistance, it is important to accumulate different $R$ genes in a single genotype based on gene pyramiding (Wang et al., 2012; Miah, 2013). In this context, DNA markers serve as significant tools to identify the resistance genes in rice breeding programs without the need for conventional inoculation methods (Hayashi et al., 2010). Although the resistance genes mainly confer resistance to a pathogen, in some instances, they also cosegregate with other marker genes associated with quantitative traits (Kidane et al., 2017; Zhang et al., 2017). Therefore, it is of high interest to understand other putative roles, if there are any, of DNA markers associated with disease resistance. The significant association between a marker gene and a trait is widely applied using associa- tion mapping approach in many crops including rice (Song et al., 2018). Since the identification of $R$ genes in Egyptian and Saudi Arabian rice has not been well-addressed, it is worthwhile to determine putative local rice genotypes that carry $R$ gene(s). In the current study, different DNA markers including SSR, SNP, and InDel were used to identify genotypes that carry resistance genes that may contribute to developing successful breeding programs. The objectives of this study were to 1 ) identify Pit, Pib, Pi39(t), Pi4O(t), Piz/Piz-t, and Pita/ Pita2 genes in 10 rice genotypes from Egypt and Saudi Arabia, 2) evaluate the agro-morphological characters of the studied genotypes, and 3) examine the putative association between resistance genes and the agro-morphological traits using association mapping.

\section{Materials and methods}

\section{Plant material}

Ten rice genotypes were used (Table 1), including two genotypes from Saudi Arabia (Al-Ahsa1 and AlAhsa2), one monogenic line from International Rice Research Institute (IRBL5-M), and seven from Egypt (Sakha104, Sakha108, Giza179, Sakha101, Eg-N-3, Eg-N-6, and Eg-N-7).

\section{Evaluation of blast reaction in blast nursery test}

The rice genotypes were evaluated for seedling reaction against $M$. oryzae under field nursery test for two seasons (2016 and 2017) in Egypt at three locations: Sakha (Kafr El Sheikh Governorate), Gemmiza (Gharbia Governorate), and Zarzora (Behera Governorate). The genotypes were left exposed for natural blast, and the typical blast lesions were scored after 40 days from sowing date. The blasts were scored according to the Standard Evaluation System using 0-9 scale (IRRI, 1996) as follows: 0-2 - resistant, 3 - moderately resistant, 4-6 - susceptible, and 7-9 - highly susceptible.

\section{Phenotypic evaluation}

The rice genotypes were grown and evaluated at the Rice Research and Training Center (RRTC), Kafr ElSheikh, Egypt, for two seasons (2016 and 2017). Randomized complete block design with three replicates was used for the analysis. In both seasons, a total of 19 agronomic traits were recorded: days to maturity, plant height $(\mathrm{cm})$, number of tillers/plant, panicle length $(\mathrm{cm})$, 
Table 1. Parentage, and origin of 10 rice genotypes used in the study

\begin{tabular}{c|c|c|c}
\hline Number & Genotypes & Parentage & Origin \\
\hline 1 & Al-Ahsa1 & exotic (Japan) & Saudi Arabia \\
\hline 2 & Al-Ahsa2 & exotic (Japan) & Saudi Arabia \\
\hline 3 & IRBL5-M & (IRRI LINES) & IRRI \\
\hline 4 & Sakha104 & Gz4096-8-1/Gz4100-9-1 & Egypt \\
\hline 5 & Sakha108 & Sakha101/HR5824//Sakha101 & Egypt \\
\hline 6 & Giza179 & Sakha101/HR5824//Sakha101 & Egypt \\
\hline 7 & Sakha101 & (Giza 176/Milyang 79) & Egypt \\
\hline 8 & Eg-N-3 & pure line selection & Egypt \\
\hline 9 & Eg-N-6 & pure line selection & Egypt \\
\hline 10 & Eg-N-7 & pure line selection & Egypt \\
\hline
\end{tabular}

number of panicles/plant, panicle weight (g), 1000-grain weight (g), number of filled grain / panicles, sterility \%, grain yield $/ \mathrm{m}^{2}$, grain length $(\mathrm{mm})$, grain width $(\mathrm{mm})$, grain shape $(\mathrm{mm})$, hulling $\%$, milling $\%$, head rice $\%$, elongation \%, gelatinization temperature, and amylose content (\%).

\section{Statistical analysis}

Analysis of variance (ANOVA) was applied for the genotypes combined over the two seasons using MSTAT-C software program (MSTATC, Michigan State University, 1992).

\section{Marker genotyping}

The genotypes were genotyped using six DNA markers including single-nucleotide polymorphisms (SNPs; T8042, NSB, and YL153/YL154), simple sequence repeats (SSRs; RM3843 and RM3330) and insertiondeletions (InDels; z4794), which were selected based on their linkage to resistance genes (Srivastava et al., 2017). Primers were obtained from Sangon Biotech, China (Table 2). Genotyping was conducted at EPCRS Center, Kafr El-Sheikh University, Egypt and Department of Agricultural Biotechnology, King Feisal University, Saudi Arabia. Total genomic DNA was isolated from the leaves of a single seedling for the 10 rice genotypes according to the protocol described by Maixner et al. (1995) with some modifications. The isolated DNA samples were amplified using polymerase chain reaction (PCR) performed in $15 \mu \mathrm{l}$ of solution under the following conditions. The reaction mixture $(25 \mu \mathrm{l})$ consisted of
$12.5 \mu \mathrm{l}$ of $2 \times$ ready-to-use master mix $(0.1 \mathrm{U} / \mu \mathrm{l}$ Taq polymerase, $500 \mu \mathrm{M}$ dNTP, $20 \mathrm{mM}$ Tris- $\mathrm{HCl}(\mathrm{pH} 8.3$ ), $100 \mathrm{mM} \mathrm{KCl}, 3 \mathrm{mM} \mathrm{MgCl}$, stabilizer, enhancer, $10 \mathrm{pmol}$ of each primer, $1 \mu \mathrm{l}$ of DNA (50 ng), and $9.5 \mu \mathrm{l}$ of PCR grade water). Amplifications were performed in a thermocycler (Bio-Rad C-1000) under the following temperature conditions: 1 ) initial denaturation at $94^{\circ} \mathrm{C}$ for 5 minutes, 2) denaturation at $94^{\circ} \mathrm{C}$ for 30 seconds, 3 ) the annealing temperature of the primers differed according to each marker $\left(42-65^{\circ} \mathrm{C}\right)$ for 1 minute, 4$)$ extension at $72^{\circ} \mathrm{C}$ for 1 minute, 5 ) steps 2,3 , and 4 were repeated for 40 cycles, and 6) final extension at $72^{\circ} \mathrm{C}$ for 10 minutes. Fragments were separated on $1.5 \%$ agarose gel stained with ethidium bromide. The gels were then photographed, and allelic sizes were determined using BioDoc Analysis software (Biometra, Germany).

\section{DNA polymorphism and genotype identification}

The genotypes were screened based on the presence or absence of a specific band (allele) in each genotype for all markers. This information will be further used in evaluating marker-trait association.

\section{Association between molecular markers and agro- morphological traits}

To determine any putative association between DNA markers and the agronomic traits, association genetic analysis was applied. First, genotypic data from the six markers were used along with information on the origin of each individual genotype to determine population structure using the model-based Bayesian clustering 
Table 2. Resistance genes and primer sequences of its linked molecular markers used in the study

\begin{tabular}{l|c|c|c|l|l|l}
\hline $\begin{array}{c}\text { Resistance } \\
\text { gene }\end{array}$ & $\begin{array}{c}\text { Marker } \\
\text { name }\end{array}$ & $\begin{array}{c}\text { Marker } \\
\text { type }\end{array}$ & Chromosome & \multicolumn{1}{|c|}{ Forward sequence $\left(5^{\prime}-3^{\prime}\right)$} & \multicolumn{1}{|l}{ Reference } \\
\hline Pit & T8042 & SNP & 1 & CTCAAGATTGTATCGTCGACGACTA & GAGAGGTTTGCAGCCAGACCAGG & Hayashi et al., 2006 \\
\hline Pib & NSb & SNP & 2 & ATCAACTCTGCCACAAAATCC & CCCATATCACCACTTGTTCCCC & Cho et al., 2007 \\
\hline Pi39(t) & RM3843 & SSR & 4 & ACCCTACTCCCAACAGTCCC & GGGGTCGTACGCTCATGTC & Terashima et al., 2008 \\
\hline Pi4O(t) & RM3330 & SSR & 6 & ATTATTCCCCTCTTCCGCTC & AAGAAACCCTCGGATTCCTG & Jeung et al., 2007 \\
\hline Piz/Piz-t & $z 4794$ & InDel & 6 & CACGCCACCCTTCAATGGAGACT & TGAATGTGAGAGGTTGACTGTGG & Hayashi et al., 2006 \\
\hline Pita/Pita2 & YL153/YL154 & SNP & 12 & CAACAATTTAATCATACACG & ATGACACCCTGCGATGCAA & Suh et al., 2009 \\
\hline
\end{tabular}


algorithm (STRUCTURE; Pritchard et al., 2000). Second, pairwise kinship coefficients among the genotypes were estimated according to Ritland (1996) using the software package SpaGeDi (Hardyand Vekemans, 2002). Marker-trait associations were determined using the unified mixed-model approach (Yu et al., 2006): $y=\mathrm{S} \alpha+$ $+\mathrm{Q} v+Z u+e$, where $y, \alpha, v, u$, and $e$ are vectors of phenotypic observations, marker effect (fixed), population effects (fixed), kinship effects (random), and residual effects, respectively, and $\mathrm{S}, \mathrm{Q}$, and $\mathrm{Z}$ are matrices of $1 \mathrm{~s}$ and $0 \mathrm{~s}$ relating $y$ to $\alpha, v$, and $u$, respectively. Geneticassociationanalyses were conducted using TASSEL version 5.0 (released October 2018, http://www.maize genetics.net), and positive associations were determined at the $P<0.05$ level.

\section{Results and discussion}

\section{Evaluation of blast reaction in blast nursery test}

The response of the rice genotypes to $M$. oryzae infection was studied at three locations (Sakha, Gemmiza, and Zarzoura), the details of which are presented in Table 3 . The results showed that five genotypes (Al-Ahsa1, Al-Ahsa2, Sakha104, Sakha101, and Eg-N-3) were susceptible/highly susceptible to blast disease in three locations except for Eg-N-3 at Sakha which was moderately resistant. The remaining genotypes were resistant to moderately resistant. On the other hand, IRBL5-M which carries the resistance gene Pi5(t) (Tsunematsu et al., 2000) was found to be resistant, while Sakha101 which carries Pita2 gene (personal communication) was found to be susceptible.

\section{ANOVA and performance of agro-morphological traits}

Analysis of variance showed that most of the observed variations were due to genotypic differences (Table 4), since a highly significant variance was observed among genotypes. For the agro-morphological traits, the studied genotypes showed wide variation in mean trait performance, and the results of the studied 19 agronomic traits are presented in Table 5 . The most important trait that affected the yield was days to maturity. AlAhsa1 had the highest number of days for maturation with a mean value of 156 days compared to Giza 179 , the latter was the earliest among the studied genotypes and had an average of 123 days to maturity. Based on the number of tillers per plant, Sakha101 and Sakha104
Table 3. Leaf blast reaction for rice genotypes at blast nursery test locations

\begin{tabular}{c|l|c|c|c}
\hline \multirow{2}{*}{ Number } & \multirow{2}{*}{ Genotypes } & \multicolumn{3}{|c}{ Test location } \\
\cline { 3 - 5 } & & Sakha & Gemmiza & Zarzora \\
\hline 1 & Al-Ahsa1 & $7^{*}$ & 5 & 6 \\
\hline 2 & Al-Ahsa2 & 7 & 4 & 6 \\
\hline 3 & IRBL5-M & 2 & 2 & 2 \\
\hline 4 & Sakha104 & 6 & 5 & 6 \\
\hline 5 & Sakha108 & 2 & 1 & 2 \\
\hline 6 & Giza179 & 1 & 2 & 2 \\
\hline 7 & Sakha101 & 6 & 6 & 5 \\
\hline 8 & Eg-N-3 & 3 & 4 & 4 \\
\hline 9 & Eg-N-6 & 2 & 2 & 3 \\
\hline 10 & Eg-N-7 & 2 & 2 & 3 \\
\hline
\end{tabular}

* Standard 0-9 scale, where 0-2 - resistant, 3 - moderately resistant, 4-6 - susceptible, 7-9 - highly susceptible reactions

showed higher mean values with 24 tillers/plant compared to the other genotypes, whereas Al-Ahasa2 and IRBL5-M showed the lowest number of tillers per plant with 15 and 16 tillers per plant, respectively. For the trait number of panicles/plant, Sakha104 exhibited the highest average of 24 compared to the mean value of 13.65 which was observed in Al-Ahsa2. With regard to panicle weight, Sakha108 showed threefold higher weight when compared to Eg-N-3. When 1000-grain weight was determined for all genotypes, IRBL5-M showed the highest average of 33.75 gm as compared to Eg-N-3, which weighed $20.48 \mathrm{gm}$. For the number of filled grains/panicle, Giza 179 had the highest mean of 150 which was 2.5-fold greater than that observed for IRBL-M. According to grain yield $/ \mathrm{m}^{2}$, the yield of Eg-N-7 was twofold higher compared to Al-Ahsa1 which showed a yield of $332.4 \mathrm{gm} / \mathrm{m}^{2}$. The observation of high variability among the studied genotypes may be the result of different genetic background of the samples. For instance, comparing the mean performance of genotypes from Saudi Arabia to that of Egypt, the former showed earliness in maturation compared to the latter. However, the Egyptian genotypes outperformed both Saudi Arabian genotypes and IRBL5-M in grain yield with approximately $45 \%$ increase. The obtained results were comparable to other studies on Egyptian rice genotypes including Giza179 and Sakha104 (Abd El-Megeed et al., 2016). 
Table 4. Analysis of variance for 10 rice genotypes for yield ant its components traits

\begin{tabular}{|c|c|c|c|c|c|c|c|c|c|c|c|}
\hline $\begin{array}{c}\text { Source } \\
\text { of variation }\end{array}$ & d.f. & $\begin{array}{l}\text { Days } \\
\text { to maturity }\end{array}$ & $\begin{array}{l}\text { Plant } \\
\text { height } \\
{[\mathrm{cm}]}\end{array}$ & $\begin{array}{c}\text { Number } \\
\text { of tillers / plant }\end{array}$ & $\begin{array}{c}\text { Panicle } \\
\text { length } \\
{[\mathrm{cm}]}\end{array}$ & $\begin{array}{c}\text { Number } \\
\text { of panicle/plant }\end{array}$ & $\begin{array}{c}\text { Panicle } \\
\text { weight } \\
\text { [g] }\end{array}$ & $\begin{array}{c}\text { 1000-grain } \\
\text { weight } \\
\text { [g] }\end{array}$ & $\begin{array}{c}\text { Number } \\
\text { of filled grain / panicles }\end{array}$ & $\begin{array}{l}\text { Sterility } \\
\text { [\%] }\end{array}$ & $\begin{array}{c}\text { Grain } \\
\text { yield } / \mathrm{m}^{2}\end{array}$ \\
\hline Replication & 2 & 0.03 & 0.63 & 1.03 & 1.64 & 0.23 & 0.00 & 0.02 & 0.43 & 0.59 & 0.25 \\
\hline Genotype & 9 & $393.87^{* *}$ & $1744.92^{* *}$ & $40.55^{* *}$ & $37.61^{* *}$ & $43.78^{* *}$ & $2.82^{* *}$ & $53.30^{* *}$ & $2478.46^{* *}$ & $988.18^{* *}$ & $43730.87^{* *}$ \\
\hline Error & 18 & 1.7 & 2.86 & 1.22 & 0.31 & 0.94 & 0.01 & 0.28 & 3.69 & 1.36 & 4.51 \\
\hline
\end{tabular}

\begin{tabular}{l|c|c|c|c|c|c|c|c|c|c}
\hline $\begin{array}{c}\text { Source } \\
\text { of variation }\end{array}$ & d.f. & $\begin{array}{c}\text { Grain } \\
\text { length } \\
{[\mathrm{mm}]}\end{array}$ & $\begin{array}{c}\text { Grain } \\
\text { width } \\
{[\mathrm{mm}]}\end{array}$ & $\begin{array}{c}\text { Grain } \\
\text { shape } \\
{[\mathrm{mm}]}\end{array}$ & $\begin{array}{c}\text { Hulling } \\
{[\%]}\end{array}$ & $\begin{array}{c}\text { Milling } \\
{[\%]}\end{array}$ & $\begin{array}{c}\text { Head } \\
\text { rice } \\
{[\%]}\end{array}$ & $\begin{array}{c}\text { Elongation } \\
{[\%]}\end{array}$ & $\begin{array}{c}\text { Amylose } \\
\text { content } \\
{[\%]}\end{array}$ \\
\hline Replication & 2 & 0.001 & 0.0001 & 0.0001 & 0.40 & 0.01 & 0.07 & 4.83 & 0.06 \\
\hline Genotype & 9 & $0.202^{* *}$ & $0.144^{* *}$ & $0.0957^{* *}$ & $68.00^{* *}$ & $59.57^{* *}$ & $600.27^{* *}$ & $783.12^{* *}$ & 0.63 \\
\hline Error & 18 & 0.002 & 0.0002 & 0.0002 & 1.03 & 0.54 & 1.45 & 2.82 & $7.41^{* *}$ & 0.26 \\
\hline
\end{tabular}

** Significant at $P<0.001$ 
Table 5. Mean performance and range of 10 Egyptian and exotic rice genotypes for yield and its components traits

\begin{tabular}{|c|c|c|c|c|c|c|c|c|c|c|}
\hline Genotype & $\begin{array}{l}\text { Days } \\
\text { to maturity }\end{array}$ & $\begin{array}{l}\text { Plant } \\
\text { height } \\
{[\mathrm{cm}]}\end{array}$ & $\begin{array}{c}\text { Number } \\
\text { of tillers / plant }\end{array}$ & $\begin{array}{l}\text { Panicle } \\
\text { length } \\
{[\mathrm{cm}]}\end{array}$ & $\begin{array}{c}\text { Number } \\
\text { of panicle / plant }\end{array}$ & $\begin{array}{c}\text { Panicle } \\
\text { weight } \\
{[\mathrm{g}]}\end{array}$ & $\begin{array}{c}\text { 1000-grain } \\
\text { weight } \\
{[\mathrm{g}]}\end{array}$ & $\begin{array}{l}\text { Number } \\
\text { of filled grain } \\
\text { / panicles }\end{array}$ & $\begin{array}{c}\text { Sterility } \\
{[\%]}\end{array}$ & $\begin{array}{c}\text { Grain } \\
\text { yield } / \mathrm{m}^{2} \\
{\left[\mathrm{gm} / \mathrm{m}^{2}\right]}\end{array}$ \\
\hline Al-Ahsa1 & 156.33 & 144.00 & 16.00 & 28.00 & 14.00 & 2.90 & 25.00 & 109.00 & 51.00 & 332.40 \\
\hline Al-Ahsa2 & 155.67 & 143.00 & 15.00 & 27.33 & 13.67 & 2.77 & 25.33 & 105.00 & 55.00 & 343.07 \\
\hline IRBL5-M & 131.33 & 135.00 & 17.00 & 18.63 & 16.33 & 2.53 & 33.75 & 85.00 & 6.83 & 366.33 \\
\hline Sakha104 & 137.00 & 104.00 & 24.67 & 21.77 & 24.00 & 4.04 & 29.51 & 134.67 & 12.13 & 527.27 \\
\hline Sakha108 & 137.00 & 96.00 & 20.33 & 23.50 & 19.67 & 4.60 & 26.48 & 148.33 & 14.79 & 504.43 \\
\hline Giza179 & 123.00 & 96.00 & 24.00 & 19.73 & 23.00 & 4.32 & 29.55 & 150.00 & 3.35 & 596.27 \\
\hline Sakha101 & 142.00 & 95.00 & 24.67 & 23.20 & 23.00 & 3.51 & 28.55 & 117.33 & 24.15 & 599.37 \\
\hline Eg-N-3 & 129.00 & 86.00 & 18.00 & 17.70 & 16.33 & 1.65 & 20.48 & 63.00 & 14.66 & 619.17 \\
\hline Eg-N-6 & 127.33 & 87.67 & 22.00 & 20.33 & 20.67 & 3.43 & 28.40 & 117.33 & 6.57 & 568.37 \\
\hline Eg-N-7 & 130.00 & 83.00 & 18.00 & 19.37 & 17.00 & 2.08 & 20.05 & 81.67 & 16.14 & 651.67 \\
\hline Range & $123.00-156.33$ & $83.00-144.00$ & $15.00-24.00$ & $19.37-28.00$ & $14.00-24.00$ & $1.65-4.60$ & $20.05-33.75$ & $81.67-150.00$ & & \\
\hline
\end{tabular}




\section{Genotype identification and allelic diversity}

Six DNA markers were used for screening of the genotypes bearing blast resistance genes. The marker T8042, linked to Pit gene, showed positive amplifications (for two alleles of size 450 and $650 \mathrm{bp}$ ) in four genotypes: Al-Ahsa1, Al-Ahsa2, Giza179, and Eg-N-3 (Fig. 1A; Table 6). However, the marker was absent in the IRBL5-M, Sakha104, Sakha108, Sakha101, Eg-N-6, and Eg-N-7 genotypes. The marker NSB, linked to $P i b$, showed positive amplification in all genotypes except IRBL5-M and Eg-N-6 (Fig. 1B). The studied marker had three different alleles $(500,600$, and $700 \mathrm{bp}$; Table 6). RM3843, linked to Pi39(t), showed positive amplification in all genotypes (Fig. 1C). The marker showed polymorphic amplification of alleles with size 180 and $200 \mathrm{bp}$ (Table 6). Al-Ahsa1, Al-Ahsa2, IRBL5-M, and Giza179 had 180-bp alleles, whereas Sakha104, Sakha108, Sakha101, Eg-N-3, Eg-N-6, and Eg-N-7 possessed the 200bp allele. RM3330 linked to Pi4O(t) showed positive amplifications for all genotypes (Fig. 1D). All genotypes except Sakha101 showed polymorphic amplification with two alleles of size 180 and $220 \mathrm{bp}$. Sakha101 had only one allele (180 bp). The molecular marker z4794 associated with Piz/Piz-t gene showed positive amplification in all the studied genotypes (Fig. 1E). The amplified alleles showed low polymorphism with two identified alleles of size 157 and $200 \mathrm{bp}$. Five genotypes (IRBL5-M, Sakha104, Eg-N-3, Eg-N-6, and Eg-N-7) had bands specific for the first allele,while the genotypes Al-Ahsa1, Al-Ahsa2, Sakha108, Giza179, and Sakha101 had bands for the second allele. Molecular marker YL153/ YL154, which is linked to Pita/ Pita-2 genotype, showed positive amplification for one allele of size $450 \mathrm{bp}$ in four genotypes (Al-Ahsa1, Al-Ahsa2, Giza179, and Eg-N-3); however, the remaining genotypes did not possess this marker (Fig. 1F).

As expected, the studied markers showed, in general, low allelic diversity. Our results corroborate with the previous findings of Yadav et al. (2019), who reported that the average number of alleles was two and the mean gene diversity was $32 \%$. In the current study, among the 10 genotypes screened for the presence of major blast resistance genes, at least one genotype had one allele of the eight major $R$ genes (Table 6 ). These results came in agreement with a previous study on rice genotypes from Egypt and Saudi Arabia (Hassan et al., 2018). They found that most of the studied genotypes had poly- morphic RM3330 alleles. Similarly, using Saudi Arabia and Egyptian rice genotypes, they obtained two alleles at 141 and $204 \mathrm{bp}$. The marker YL153/YL154, which is linked to Pita/Pita-2, showed only one allele at $450 \mathrm{bp}$. Among the studied genotypes, Al-Ahsa1, Al-Ahsa2, Giza179 and Eg-N-3 showed positive amplification of the 450-bp allele, which is found to be specific for these genotypes. In addition, Hassan et al. (2018) also reported similar results where YL153/YL154 alleles were detected in Al-Ahsa1 and Al-Ahsa2. The results of blastspecific marker amplifications revealed that the studied genotypes showed the presence of a wide array of blast resistance genes. The Egyptian genotype Eg-N-7 had only RM3330 associated with $P i 40(\mathrm{t})$, whereas all the studied markers were present in the Egyptian genotype Giza179 and the Saudi Arabian genotype Al-Ahsa1 (Table 6). Additionally, four markers were identified in Sakha104, Sakha108, and Eg-N-3. The use of molecular markers for the identification of rice genotypes carrying resistance genes is well-established in different geographic regions (Liu et al., 2015; Zhang et al., 2015; Yadav et al., 2019); however, in Egypt and Saudi Arabia, research related to the identification of resistance genes in rice is still in preliminary stages.

\section{Genetic association between molecular markers and the agro-morphological traits}

Association mapping analysis identified eight significant marker-trait associations $(P<0.05)$ for eight agromorphological traits: plant height, panicle length, sterility $\%$, grain width, grain shape, elongation $\%$, gelatinization temperature, and days to maturity (Table 7). Among the studied markers, NSB showed significant associations with four traits (panicle length, sterility \%, gelatinization temperature, and days to maturity), whereas RM3843 was significantly associated with two traits (plant height and grain shape). However, both YL153/ YL154 and z4794 were associated with one trait (elongation \%). On the other hand, no marker-trait association was detected with T8042. The phenotypic variance $\left(R^{2}\right)$ shown by each marker was moderate and ranged between 43\% for YL153/YL154 (associated with elongation \%) and 65\% for RM3843 (associated with grain shape) (Table 7). One of the major roles of association mapping is evaluating the performance of marker-phenotype combination in a group of individuals (Zondervan and Cardon, 2004). In breeding programs, association 
Table 6. Alleles detected and its molecular weight (mw) in base pare (bp) in 10 rice genotypes ( 1 - allele is present and 0 - allele is absent)

\begin{tabular}{l|c|c|c|c|c|c|c|c|c|c|c|c}
\hline Resistance gene & \multicolumn{2}{|c|}{ Pit } & \multicolumn{3}{c|}{ Pib } & \multicolumn{2}{c|}{ Pi39(t) } & \multicolumn{2}{c|}{ Pi40(t) } & \multicolumn{2}{c}{ Piz/Piz-t } & Pita/ Pita-2 \\
\hline Molecular marker & \multicolumn{2}{|c|}{ T8042 } & \multicolumn{3}{c}{ NSB } & \multicolumn{2}{c}{ RM3843 } & RM3330 & \multicolumn{2}{|c}{ z4794 } & YL153/YL154 \\
\hline Allele mw (bp) & 450 & 650 & 500 & 600 & 700 & 180 & 200 & 180 & 220 & 157 & 200 & 450 \\
\hline Al-Ahsa1 & 1 & 1 & 1 & 1 & 0 & 1 & 0 & 1 & 1 & 0 & 1 & 1 \\
\hline Al-Ahsa2 & 1 & 1 & 1 & 1 & 0 & 1 & 0 & 1 & 1 & 0 & 1 & 1 \\
\hline IRBL5-M & 0 & 0 & 0 & 0 & 0 & 1 & 0 & 1 & 1 & 1 & 0 & 0 \\
\hline Sakha104 & 0 & 0 & 1 & 0 & 0 & 0 & 1 & 1 & 1 & 1 & 0 & 0 \\
\hline Sakha108 & 0 & 0 & 0 & 1 & 0 & 0 & 1 & 1 & 1 & 0 & 1 & 0 \\
\hline Giza179 & 1 & 1 & 0 & 1 & 0 & 1 & 0 & 1 & 1 & 0 & 1 & 1 \\
\hline Sakha101 & 0 & 0 & 0 & 1 & 1 & 0 & 1 & 1 & 0 & 0 & 1 & 0 \\
\hline Eg-N-3 & 0 & 1 & 0 & 0 & 0 & 0 & 1 & 1 & 1 & 1 & 0 & 1 \\
\hline Eg-N-6 & 0 & 0 & 0 & 0 & 0 & 0 & 1 & 1 & 1 & 1 & 0 & 0 \\
\hline Eg-N-7 & 0 & 0 & 1 & 1 & 1 & 0 & 1 & 1 & 1 & 1 & 0 & 0 \\
\hline
\end{tabular}

A

B

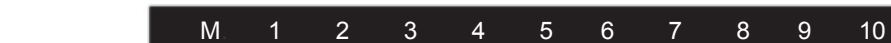

C
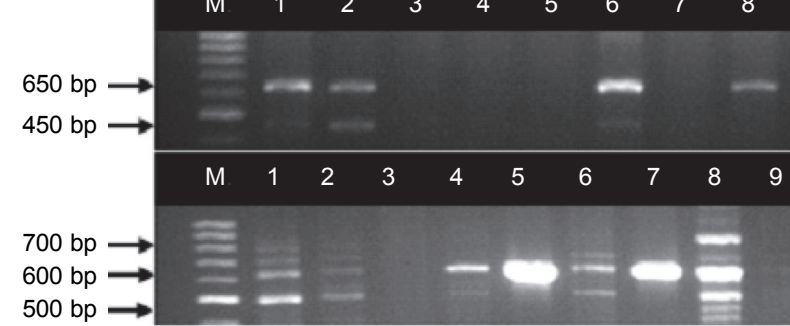

$\begin{array}{lllllllllll}\text { M } & 1 & 2 & 3 & 4 & 5 & 6 & 7 & 8 & 9 & 10\end{array}$
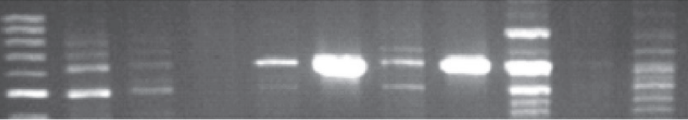

$\begin{array}{lllllllllll}M & 1 & 2 & 3 & 4 & 5 & 6 & 7 & 8 & 9 & 10\end{array}$

D
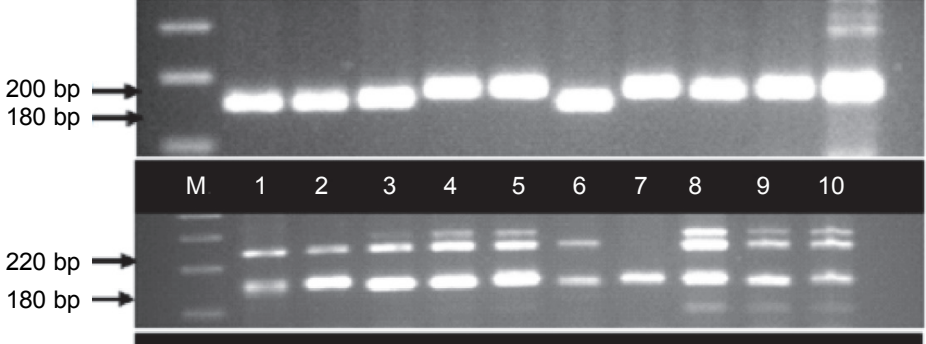

$E$

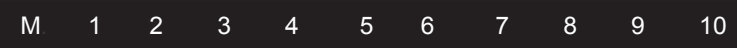

F
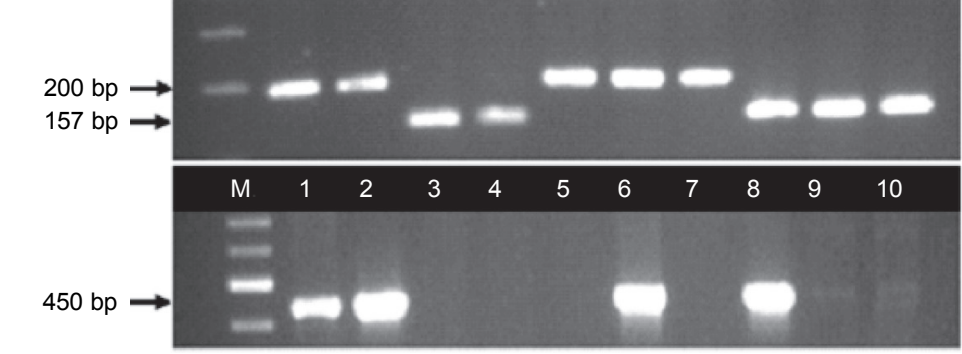

Fig. 1. Amplification pattern of A) T8042, B) NSB, C) RM3843, D) RM3330, E) z4794, and F) YL153/YL154. M; 100 bp DNA ladder, 1-10; denotes the 10 rice genotypes included in the study, arrows indicate the specific amplified alleles 
Table 7. Associations between resistance gene markers and yield and grain quality traits in 10 rice genotypes showing the marker, its significance level $(P)$ and its attributable percent of phenotypic variance $\left(R^{2}\right)$

\begin{tabular}{l|l|c|c|c}
\hline \multicolumn{1}{c|}{ Trait } & Marker & $P$-value & $R^{2}$ \\
\hline \multirow{4}{*}{ Yield } & plant height [cm] & NSB & 0.059 & 0.42 \\
\cline { 2 - 5 } & panicle length [cm] & RM3843 & $0.012^{*}$ & 0.621 \\
\cline { 2 - 5 } & & NSB & $0.028^{*}$ & 0.52 \\
\cline { 2 - 5 } & sterility [\%] & z4794 & 0.063 & 0.431 \\
\hline \multirow{5}{*}{ Grain } & grain width [mm] & NSB & $0.035^{*}$ & 0.494 \\
\cline { 2 - 5 } & grain shape [mm] & RM3843/YL154 & $0.026^{*}$ & 0.53 \\
\cline { 2 - 5 } & grain shape [mm] & RM3843 & 0.055 & 0.431 \\
\cline { 2 - 5 } & elongation [\%] & z4794 & $0.008^{*}$ & 0.658 \\
\cline { 2 - 5 } & gelatinization temperature & YL153/YL154 & 0.060 & 0.636 \\
\cline { 2 - 5 } & amylose content [\%] & RM38 & $0.047^{*}$ & 0.454 \\
\cline { 2 - 5 } & days to maturity & NSB & 0.056 & 0.429 \\
\hline
\end{tabular}

* Significant at $P<0.05$

mapping plays a crucial role in the identification of possible donor plants that are needed for the improvement (Choudhury et al., 2014) of rice cultivars. Although the markers used in the current study were previously reported to be tightly linked to the blast resistance genes (Srivastava et al., 2017), the association analysis demonstrated the possible effect of these markers on the agro-morphological traits. These results were in accordance with those reported by a genome-wide association study conducted in wheat (Kidane et al., 2017). In their study, the authors pointed out that the presence of putative quantitative trait loci (QTL) is associated with blotch resistance, which were also found to be overlapped with the QTL associated with different agronomic traits.

\section{Conclusions}

The results of the current study highlight the importance of DNA markers in the screening of rice genotypes and in breeding programs. The resistance gene(s) present in the native varieties will serve as the essential material for the breeding programs that aim to control blast disease. More importantly, the recent developments in marker-assisted breeding will promote the pyramiding of multiple genes controlling multiple traits, which in turn will play a significant role in controlling various biotic and abiotic stress responses. Potential genotypes, which have been proven to be blast resistant, could be utilized in association studies for dual purposes: first, for the identification of resistance gene(s) in local genotypes, and second, for the determination of the putative effect of such genes(s) on the agronomic performance. Association mapping revealed low number of marker-trait associations. However, the low allelic diversity at the studied loci, which can be attributed to specific marker genes, was adequate to statistically address the marker-trait association between specific markers and the agronomic traits. The phenotypic and genotypic data included in the current study could provide insights into understanding phenotype-genotype relationship through performing association mapping studies for rice blast resistance genes.

\section{Acknowledgment}

This study was supported by the Deanship of Scientific Research, King Faisal University, Saudi Arabia (Grant no. 186168). The authors would like to thank Rice Research and Training Center (RRTC), Kafr El-Sheikh, Egypt and EPCRS Center, Kafr El-Sheikh University, Egypt, for their cooperation and assistance in this research.

\section{References}

Abd El-Megeed T.M., El-Kallawy W.H., Osman M.M.A. (2016) Performance of some Egyptian rice varieties for some agronomical and physiological traits. J. Agric. Res. Kafr ElSheikh Univ. 42: 127-135. 
Aksoy M. A., Beghin J.C. eds. (2005) Global agricultural trade and developing countries. Washington DC, The World Bank.

Causse M.A., Fulton T.M., Cho Y.G., Ahn S.N., Chunwongse J. (1994) Saturated molecular map of the rice genome based on an interspecific backcross population. Genetics 138: $1251-1274$.

Cho Y.C., Kwon S.W., Choi I.S., Lee S.K. et al. (2007) Identification of major blast resistance genes in Korean rice varieties (Oryza sativa L.) using molecular markers. J. Crop Sci. Biotech. 10: 223-234.

Choudhury D.R., Singh N., Singh A.K., Kumar S. et al. (2014) Analysis of genetic diversity and population structure of rice germplasm from North-eastern region of India and development of a core germplasm set. PLOS One 9: e113094.

Fukuoka S., Saka N., Koga H., Ono K. et al. (2009) Loss of function of a proline-containing protein confers durable disease resistance in rice. Science 325: 998-1001.

Fukuoka S., Yamamoto S.I., Mizobuchi R., Yamanouchi U. et al. (2014) Multiple functional polymorphisms in a single disease resistance gene in rice enhance durable resistance to blast. Sci. Rep. 4: 4550.

Hardy O.J., Vekemans X. (2002) SPAGeDi: a versatile computer program to analyse spatial gen-etic structure at the individual or population levels. Mol. Ecol. Notes 2: 618-620.

Hassan S.M.A., Omar A.A., Mohamed M.E., Ehab M.R.M. et al. (2018) Development of nutrient-rich and blast-resistant rice cultivars through tissue culture and monogenic lines. Int. J. Agric. Biol. 20: 2508-2520.

Hayashi K., Yasuda N., Fujita Y., Koizumi S. et al. (2010) Identification of the blast resistance gene Pit in rice cultivars using functional markers. Theor. Appl. Genet. 121: 1357-1367.

Hayashi K., Yoshida H., Ashikawa I. (2006) Development of PCR-based allele specific and InDel marker sets for nine rice blast resistance genes. Theor. Appl. Genet. 113: 251-260.

Huda M.N., Hasan M., Abdullah H.M., Sarker U. (2019) Spatial distribution and genetic diversity of wild date palm (Phoenix sylvestris) growing in coastal Bangladesh. Tree Genet. Genomes. 15: 2-11.

IRRI (1996) Standard evaluation system for rice. International Rice Research Institute, Los Baños, Philippines.

Khush G.S. (2005) What it will take to feed 5.0 billion rice consumers in 2030. Plant Mol. Biol. 59: 1-6.

Kidane Y.G., Hailemariam B.N., Mengistu D. K., Fadda C. (2017) Genome wide association study of Septoriatritici blotch resistance in Ethiopian durum wheat landraces. Front. Plant Sci. 8: 1586.

Li Y.B., Wu C. J., Jiang G. H., Wang L. Q., et al. (2007) Dynamic analyses of rice blast resistance for the assessment of genetic and environmental effects. Plant Breed. 126: 541-547.

Liao J., Huang H., Meusnier I., Adreit H., Ducasse et al. (2016) Pathogen effectors and plant immunity determine specialization of the blast fungus to rice subspecies. eLife 5: e19377.

Liu Y., Qi X., Young N.D., Olsen K.M. et al. (2015) Characterization of resistance genes to rice blast fungus Magnaportheoryzae in a "Green Revolution" rice variety. Mol. Breed. 35: 1-8.

Maixner M., Ahrens U., Seemüller E. (1995) Detection of the German grapevine yellows (Vergilbungskrankheit) MLO in grapevine, alternative hosts and a vector by a specific PCR procedure. Eur. J. Plant Pathol. 101: 241-250.

Matsumoto T., Wu J.Z., Kanamori H., Katayose Y. et al. (2005) The map-based sequence of the rice genome. Nature 436: 793-800.

Miah G., Rafii M.Y., Ismail M.R., Puteh A.B., Rahim H.A. et al. (2013) Blast resistance in rice: a review of conventional breeding to molecular approaches. Mol. Biol. Rep. 40: 2369-2388.

Muthayya S., Sugimoto J.D., Montgomery S., Maberly G.F. (2014) An overview of global rice production, supply, trade, and consumption. Ann. N. Y. Acad. Sci. 1324: 7-14.

Pritchard J.K., Stephens P., Donnelly P. (2000) Inference of population structure using multilocus genotype data. Genetics 155: 945-959.

Ritland K. (1996) Estimators for pairwise relatedness and individual inbreeding coefficients. Genet. Res. 67: 175-186.

Skamnioti P., Gurr S.J. (2009) Against the grain: safeguarding rice from rice blast disease. Trends Biotechnol. 27: 141-150.

Song J., Li J., Sun J., Hu T., et al. (2018) Genome-wide association mapping for cold tolerance in a core collection of rice (Oryza sativa L.) landraces by using high-density single nucleotide polymorphism markers from specificlocus amplified fragment sequencing. Front. Plant Sci. 9: 875.

Srivastava D., Shamim M., Kumar M., Mishra A. et al. (2017) Current status of conventional and molecular interventions for blast resistance in rice. Rice Sci. 24: 299-321.

Tsunematsu H., Yanoria M.J.T., Ebron L.A., N. Hayashi et al. (2000) Development of monogenic lines of rice for blast resistance. Breed. Sci. 50: 229-234.

Wang G.L., Mackill D.J., Bonman J.M., McCouch S.R., et al. (1994) RFLP mapping of genes conferring complete and partial resistance to blast in a durably resistant rice cultivar. Genetics 136: 1421-1434.

Wang X., Lee S., Wang J., Ma J. et al. (2014) Current advances on genetic resistance to rice blast disease. [in:] Rice Germplasm, Genetics and Improvement. Ed. Yan W., Bao J. In Tech, Rijeka, Croatia: 195-217.

Wang Y., Wang D., Deng X., Liu J., et al. (2012) Molecular mapping of the blast resistance genes Pi2-1 and Pi51(t) in the durably resistant rice 'Tianjingyeshengdao'. Phytopathology 102: 779-786.

Yadav M.K., Aravindan S., Gangkham U.N, S. Raghu, et al. (2019) Blast resistance in Indian rice landraces: Genetic dissection by gene specific markers. PLoSONE 14: $\mathrm{e} 0211061$. 
Yang S., Li J., Zhang X., Zhang Q., et al. (2013) Rapidly evolving $R$ genes in diverse grass species confer resistance to rice blast disease. Proc. Natl. Acad. Sci. USA. 110: 18572-18577.

Yildirim A., Kahraman A., Muehlbauer F.J., Tanyolac B. (2018) Identification of new QTL conferring resistance to anthracnose (Ascochyta rabiei) im a ril population of chickpea. Turk. J. Field Crops 23: 93-99

Yu J., Pressoir G., Briggs W.H., Vroh Bi. I., et al. (2006) A unified mixed-model method for association mapping that accounts for multiple levels of relatedness. Nat. Genet. 38: 203-208.
Zhang X., Zhang J., He X., Wang Y. et al. (2017) Genome wide association study of major agronomic traits related to domestication in peanut. Front. Plant Sci. 8: 1611.

Zhang X.H., Yang S.H., Wang J., Jia Y.X., et al. (2015) A genome wide survey reveals abundant rice blast $R$ genes in resistant cultivars. Plant J. 84: 20-28.

Zondervan K.T., Cardon L.R. (2004) The complex interplay among factors that influence allelic association. Nat. Rev. Genet. 5: 89-100. 